\title{
Health behaviours of pregnant women and gestational weight gains - a pilot study
}

\section{Zachowania zdrowotne kobiet w ciąży a wielkość ciążowych przyrostów masy ciała - wstępne wyniki}

\author{
Edyta Suliga', Olga K. Adamczyk-Gruszka² \\ 1Department of the Prevention of Alimentary Tract Diseases, Faculty of Medicine and Health Science, Jan Kochanowski University, \\ Kielce, Poland \\ Head of the Department: Prof. Grażyna Rydzewska MD, PhD \\ 2Department of Gynecological and Obstetric Prophylaxis, Faculty of Medicine and Health Science, Jan Kochanowski University, \\ Kielce, Poland \\ Head of the Department: Prof. Wojciech Rokita MD, PhD
}

Key words: body mass index, gestational weight gain, eating habits.

Słowa kluczowe: wskaźnik masy ciała, ciążowe przyrosty masy, żywienie.

\begin{abstract}
Introduction: Abnormal weight gain during pregnancy may exert a negative effect on the development of the foetus, the course of pregnancy, and later the state of health of the mother and her baby. Due to the unfavourable health consequences of abnormal body weight gains in expectant mothers studies of the factors that determine the amount of these gains are important.

Aim of the research: Evaluation of the relationship between health behaviours in pregnancy, nutritional status before pregnancy, selected socio-demographic factors, and gestational weight gain.

Material and methods: The investigation included 274 women. Using a questionnaire, information was collected pertaining to the place of residence, age, body height and weight, cigarette smoking, and eating habits during pregnancy. The total weight gain during pregnancy was calculated as the difference between perinatal weight and pre-pregnancy body weight. Gestational weight gains were classified as low, recommended, or high.

Results: Increased risk of high weight gain was associated with the consumption of alcoholic beverages (odds ratio $(\mathrm{OR})=2.82$ ), especially beer $(\mathrm{OR}=2.72)$, high consumption of products supplying proteins of animal origin $(\mathrm{OR}=2.87)$, and overweight before pregnancy ( $\mathrm{OR}=3.37)$, as well as the delivery being the mother's first, compared to the third and subsequent childbirth $(\mathrm{OR}=4.17)$. Conclusions: This study indicates that there is a need for health education among females at reproductive age in order to reduce excess weight before conception, and promotion of adequate health behaviours in pregnancy, which would allow the maintenance of normal weight gain during this period.
\end{abstract}

\section{Streszczenie}

Wprowadzenie: Nieprawidłowe przyrosty masy ciała kobiet w ciąży mogą negatywnie wpływać na rozwój płodu, przebieg porodu oraz późniejszy stan zdrowia matki i dziecka. Niekorzystne konsekwencje zdrowotne nieprawidłowych przyrostów masy ciała przyszłych matek sprawiają, że istotne są badania czynników determinujących ich wielkość.

Cel pracy: Ocena zależności pomiędzy zachowaniami zdrowotnymi w czasie ciąży, stanem odżywienia przed ciążą oraz niektórymi czynnikami socjodemograficznymi a wielkością przyrostów masy ciała w ciąży.

Materiał i metody: Badaniem objęto 274 kobiety. Za pomocą ankiety zebrano informacje na temat miejsca zamieszkania, wieku, wysokości i masy ciała, palenia papierosów oraz sposobu żywienia w czasie ciąży. Całkowity przyrost masy ciała w czasie ciąży obliczono jako różnicę między okołoporodową a przedciążową masą ciała. Przyrosty masy ciała w ciąży klasyfikowano jako niskie, zalecane lub wysokie.

Wyniki: Przyrost masy w ciąży sklasyfikowany jako zalecany w odniesieniu do wskaźnika masy ciała przed ciążą odnotowano jedynie u 37\% pacjentek, a u niemal 40\% stwierdzono wysokie przyrosty. Konsumpcja w czasie ciąży napojów alkoholowych $(\mathrm{OR}=2,82)$, zwłaszcza piwa $(\mathrm{OR}=2,72)$, wysokie spożycie produktów dostarczających białka zwierzęcego, tj. 3 lub więcej porcji w ciągu dnia $(\mathrm{OR}=2,86)$, a także nadwaga przed ciążą $(\mathrm{OR}=3,37)$ oraz pierwszy poród w porównaniu z trzecim lub kolejnym $(\mathrm{OR}=4,17)$ wiązały się ze zwiększonym ryzykiem wystąpienia wysokich przyrostów masy ciała.

Wnioski: Przeprowadzone badania wskazują na potrzebę edukacji zdrowotnej kobiet w wieku rozrodczym w celu zmniejszenia nadmiarów masy ciała przed zajściem w ciążę oraz promowania właściwych zachowań zdrowotnych w czasie ciąży, które pozwolą na utrzymanie prawidłowych przyrostów masy w tym okresie. 


\section{Introduction}

Abnormal weight gain during pregnancy may exert a negative effect on the development of the foetus, the course of pregnancy, and the later state of health of the mother and her baby. In recent years, an alarming phenomenon has been observed: the increasingly frequent occurrence of excessive body weight gain during pregnancy $[1,2]$. This is associated with the risk of giving birth to a large-for-gestational-age baby, macrosomia, shoulder dystocia, pregnancy-induced hypertension, gestational diabetes, caesarean section, longer period of hospitalisation, and the mother maintaining an increased postpartum body weight, which predisposed to later obesity [3-6]. Due to the unfavourable health consequences of abnormal body weight gains in expectant mothers studies of the factors that determine the amount of these gains are important.

\section{Aim of the research}

The objective of the study was an evaluation of the relationship between health behaviours in pregnancy, nutritional status before pregnancy, selected sociodemographic factors, and gestational weight gain.

Table 1. General characteristics of the women examined

\begin{tabular}{|c|c|c|c|}
\hline Factors & & $N$ & Percentage \\
\hline \multirow[t]{2}{*}{ Place of living } & City & 111 & 51.9 \\
\hline & Village & 107 & 48.1 \\
\hline \multirow[t]{2}{*}{ Age [years] } & $<30$ & 133 & 58.0 \\
\hline & $\geq 30$ & 85 & 42.0 \\
\hline \multirow[t]{3}{*}{ Birth order } & First & 97 & 48.7 \\
\hline & Second & 83 & 40.3 \\
\hline & $\begin{array}{c}\text { Third or } \\
\text { subsequent }\end{array}$ & 17 & 11.0 \\
\hline \multirow{3}{*}{$\begin{array}{l}\text { Pre-pregnancy } \\
\mathrm{BMI}\left[\mathrm{kg} / \mathrm{m}^{2}\right]\end{array}$} & $<18.5$ & 13 & 7.6 \\
\hline & $18.5-24.9$ & 162 & 72.9 \\
\hline & $\geq 25.0$ & 43 & 19.5 \\
\hline \multirow{3}{*}{$\begin{array}{l}\text { Gestational } \\
\text { weight gain }\end{array}$} & Low & 51 & 23.4 \\
\hline & Recommended & 80 & 36.7 \\
\hline & High & 87 & 39.9 \\
\hline \multirow{3}{*}{$\begin{array}{l}\text { Cigarette } \\
\text { smoking during } \\
\text { pregnancy }\end{array}$} & Non-smokers & 151 & 70.4 \\
\hline & Exposed & 42 & 19.5 \\
\hline & Smokers & 22 & 10.1 \\
\hline \multirow{2}{*}{$\begin{array}{l}\text { Alcohol } \\
\text { consumption } \\
\text { during pregnancy }\end{array}$} & No & 147 & 79.8 \\
\hline & Yes & 44 & 20.2 \\
\hline
\end{tabular}

\section{Material and methods}

The research material was data concerning 274 women who during delivery were hospitalised in the Clinic of Obstetrics and Gynaecology at the Regional Polyclinic Hospital in Kielce. In the study were women enrolled who delivered a healthy baby (without congenital defects). Two patients with twin pregnancy, 43 patients who gave birth before 38 weeks of gestation, and 4 patients with gestational diabetes were excluded from further analysis. Data concerning birth order, and the course and duration of pregnancy was obtained based on the analysis of medical records. Using a questionnaire, information was collected pertaining to the place of residence, age, body height and weight, cigarette smoking, and eating habits during pregnancy. The questions in the survey related to the number of portions of individual groups of food products consumed. The size of food portions was determined in accordance with the principles presented in the relevant literature [7]. The nutritional status prior to pregnancy was assessed based on the declared data concerning body height and weight, which served to calculate the body mass index (BMI), and groups of patients distinguished with: underweight $\left(\mathrm{BMI}<18.5 \mathrm{~kg} / \mathrm{m}^{2}\right)$, normal body weight $(18.5-24.9 \mathrm{~kg} /$ $\mathrm{m}^{2}$ ), and overweight or obesity (BMI $\left.\geq 25 \mathrm{~kg} / \mathrm{m}^{2}\right)$. The total weight gain during pregnancy was calculated as the difference between perinatal weight and pre-pregnancy body weight. Gestational weight gains were classified as low, recommended, or high, according to the guidelines of the Institute of Medicine (IOM) and National Academy of Sciences (NAS) in the USA [1]. The recommended weight gain for women who were underweight before pregnancy is $12.5-18.0 \mathrm{~kg}$, with a normal body weight $11.5-16.0 \mathrm{~kg}$, while for overweight and obese women it is $7-11.5 \mathrm{~kg}$ and $5-9 \mathrm{~kg}$, respectively. The study was approved by the Committee on Bioethics at the Faculty of Health Sciences.

\section{Statistical analysis}

Statistical analysis was performed using software Statistica 6.0 (StatSoft). For assessment of the differences between health behaviours, state of nutrition before pregnancy, socio-demographic factors, and the amount of gestational weight gains the $\chi^{2}$ test for the highest reliability was applied (Tables 1-4). The risk of occurrence of high and low body weight gain in pregnancy was evaluated using logistic regression (Table 5). Values of $p<0.05$ were considered statistically significant.

\section{Results}

The characteristics of the study participants are shown in Table 1. Overweight and obesity before pregnancy was observed in nearly $1 / 5$ of respondents. Gestational weight gain, classified as recommended in 
Table 2. Percentage of women with low, recommended, and high gestational weight gain

\begin{tabular}{|c|c|c|c|c|}
\hline \multirow[t]{2}{*}{ Factors } & & \multicolumn{3}{|c|}{ Gestational weight gain } \\
\hline & & Low & Recommended & High \\
\hline \multirow{3}{*}{$\begin{array}{l}\text { Pre-pregnancy BMI } \\
p=0.0004\end{array}$} & $<18.5$ & 11.8 & 6.3 & 2.3 \\
\hline & $18.5-24.9$ & 80.4 & 81.3 & 64.4 \\
\hline & $\geq 25.0$ & 7.8 & 12.5 & 33.3 \\
\hline \multirow{3}{*}{$\begin{array}{l}\text { Birth order } \\
p=0.0055\end{array}$} & First & 31.9 & 44.4 & 64.1 \\
\hline & Second & 55.3 & 44.4 & 32.1 \\
\hline & Third or subsequent & 12.8 & 11.1 & 3.9 \\
\hline \multirow{2}{*}{$\begin{array}{l}\text { Age } \\
p=0.2430\end{array}$} & $<30$ years & 51.0 & 65.0 & 63.2 \\
\hline & $\geq 30$ years & 49.0 & 35.0 & 36.8 \\
\hline \multirow{2}{*}{$\begin{array}{l}\text { Place of residence } \\
p=0.1300\end{array}$} & City & 54.9 & 55.0 & 44.8 \\
\hline & Village & 45.1 & 45.0 & 55.2 \\
\hline \multirow{3}{*}{$\begin{array}{l}\text { Cigarette smoking during } \\
\text { pregnancy } \\
p=0.4131\end{array}$} & Non-smokers & 72.0 & 76.0 & 64.0 \\
\hline & Exposed & 16.0 & 17.7 & 23.3 \\
\hline & Smokers & 12.0 & 6.3 & 12.8 \\
\hline
\end{tabular}

Table 3. Percentage of women with low, recommended, and high gestational weight gain according to frequency of consumption of selected products during pregnancy

\begin{tabular}{|c|c|c|c|c|}
\hline \multirow[t]{2}{*}{ Products and meals } & \multirow[t]{2}{*}{ Number of servings } & \multicolumn{3}{|c|}{ Gestational weight gain } \\
\hline & & Low & Recommended & High \\
\hline \multirow{3}{*}{$\begin{array}{l}\text { Fruit } \\
p=0.1889\end{array}$} & $<1$ serving daily & 9.8 & 8.8 & 9.2 \\
\hline & 1-2 servings daily & 52.9 & 67.5 & 50.6 \\
\hline & $\geq 3$ servings daily & 37.3 & 23.8 & 40.2 \\
\hline \multirow{3}{*}{$\begin{array}{l}\text { Vegetables } \\
p=0.5303\end{array}$} & $<1$ serving daily & 23.5 & 18.7 & 17.3 \\
\hline & $1-2$ servings daily & 43.2 & 57.5 & 51.7 \\
\hline & $\geq 3$ servings daily & 33.3 & 23.8 & 31.0 \\
\hline \multirow{3}{*}{$\begin{array}{l}\text { Milk and dairy products } \\
\text { in total } \\
p=0.1889\end{array}$} & $<1$ serving daily & 21.6 & 25.0 & 21.8 \\
\hline & 1-2 servings daily & 56.9 & 62.5 & 50.6 \\
\hline & $\geq 3$ servings daily & 21.6 & 12.5 & 27.6 \\
\hline \multirow{3}{*}{$\begin{array}{l}\text { Animal protein (meat, fish, } \\
\text { eggs) } \\
p=0.0260\end{array}$} & $<1$ servings daily or never & 25.5 & 16.3 & 25.3 \\
\hline & 1-2 servings daily & 60.8 & 68.7 & 46.0 \\
\hline & $\geq 3$ servings daily & 13.7 & 15.0 & 28.7 \\
\hline \multirow{3}{*}{$\begin{array}{l}\text { Sea fish } \\
p=0.3452\end{array}$} & Never & 15.7 & 11.2 & 17.3 \\
\hline & $<1$ serving weekly & 35.3 & 51.3 & 47.1 \\
\hline & $\geq 1$ serving weekly & 49.0 & 37.5 & 35.6 \\
\hline \multirow{3}{*}{$\begin{array}{l}\text { Sweets, cakes } \\
p=0.3692\end{array}$} & $\leq 3$ servings weekly & 51.0 & 53.7 & 39.1 \\
\hline & 4-7 servings weekly & 29.4 & 27.5 & 33.3 \\
\hline & $>1$ serving daily & 19.6 & 18.8 & 27.6 \\
\hline \multirow{3}{*}{$\begin{array}{l}\text { Number of meals daily } \\
p=0.0521\end{array}$} & $\leq 3$ & 21.6 & 5.0 & 14.9 \\
\hline & 4 & 29.4 & 40.0 & 37.9 \\
\hline & $\geq 5$ & 49.0 & 55.0 & 47.2 \\
\hline \multirow{3}{*}{$\begin{array}{l}\text { Snacking between meals } \\
p=0.0699\end{array}$} & $<1$ daily & 26.0 & 46.2 & 32.2 \\
\hline & 1 daily & 48.0 & 30.0 & 33.3 \\
\hline & $>1$ daily & 26.0 & 23.8 & 34.5 \\
\hline
\end{tabular}


Table 4. Percentage of women with low, recommended, and high gestational weight gain according to frequency of consumption of selected beverages during pregnancy

\begin{tabular}{|c|c|c|c|c|}
\hline \multirow[t]{2}{*}{ Beverages } & \multirow[t]{2}{*}{ Number of servings } & \multicolumn{3}{|c|}{ Gestational weight gain } \\
\hline & & Low & Recommended & High \\
\hline \multirow{3}{*}{$\begin{array}{l}\text { Sweetened carbonated } \\
\text { beverages } \\
p=0.6856\end{array}$} & Never & 41.2 & 37.5 & 36.8 \\
\hline & $\leq 3$ glasses weekly & 41.2 & 43.7 & 36.8 \\
\hline & $\geq 4$ glasses weekly & 17.7 & 18.8 & 26.4 \\
\hline \multirow{3}{*}{$\begin{array}{l}\text { Fruit juice } \\
p=0.4509\end{array}$} & $<1$ glass weekly or never & 23.5 & 21.5 & 15.0 \\
\hline & 1-6 glasses weekly & 41.2 & 36.7 & 49.4 \\
\hline & $\geq 1$ glass daily & 35.3 & 41.8 & 35.6 \\
\hline \multirow{3}{*}{$\begin{array}{l}\text { Milk } \\
p=0.7250\end{array}$} & $<1$ glass weekly or never & 32.0 & 33.7 & 33.3 \\
\hline & 1-6 glasses weekly & 32.0 & 38.8 & 41.4 \\
\hline & $\geq 1$ glass daily & 36.0 & 27.5 & 25.3 \\
\hline \multirow{2}{*}{$\begin{array}{l}\text { Consumption of alcohol } \\
p=0.0286\end{array}$} & No & 82.4 & 87.5 & 71.3 \\
\hline & Yes & 17.7 & 12.5 & 28.7 \\
\hline \multirow{2}{*}{$\begin{array}{l}\text { Consumption of beer } \\
p=0.0451\end{array}$} & No & 90.2 & 91.3 & 79.3 \\
\hline & Yes & 9.8 & 8.8 & 20.7 \\
\hline
\end{tabular}

Table 5. Statistically significant factors related with an increased risk of high body weight gain in pregnancy

\begin{tabular}{|c|c|c|c|}
\hline Factors & & OR & $95 \% \mathrm{Cl}$ \\
\hline \multirow[t]{3}{*}{ Pre-pregnancy BMI [kg/m²] } & $\geq 25.0$ & 3.37 & $1.51-7.51$ \\
\hline & $18.5-24.9$ & 1.00 & - \\
\hline & $<18.5$ & 0.46 & $0.09-2.49$ \\
\hline \multirow[t]{3}{*}{ Birth order } & Third or subsequent & 1.00 & - \\
\hline & Second & 2.08 & $0.50-8.67$ \\
\hline & First & 4.17 & $1.03-16.88$ \\
\hline \multirow{2}{*}{$\begin{array}{l}\text { Consumption of products supplying protein } \\
\text { of animal origin (meat, fish, eggs) }\end{array}$} & Mediocre (1-2 servings daily) & 1.00 & - \\
\hline & High ( $\geq 3$ servings daily) & 2.86 & $1.26-6.34$ \\
\hline \multirow[t]{2}{*}{ Consumption of alcohol during pregnancy } & No & 1.00 & - \\
\hline & Yes & 2.82 & $1.26-6.34$ \\
\hline \multirow[t]{2}{*}{ Consumption of beer during pregnancy } & No & 1.00 & - \\
\hline & Yes & 2.72 & $1.07-6.92$ \\
\hline
\end{tabular}

relation to the pre-pregnancy BMI value, was noted in less than $37 \%$ of patients, and high gains were found in almost $40 \%$. Every $5^{\text {th }}$ woman consumed alcoholic beverages during pregnancy, and every $10^{\text {th }}$ woman declared that she smoked cigarettes, whereas nearly every $5^{\text {th }}$ was exposed to tobacco smoke in her nearest environment.

High body weight gains occurred in $1 / 3$ of patients who were overweight before pregnancy and, most rarely, in only $2.3 \%$ of underweight women, also, in patients who gave birth for the first time, while most rarely in those who delivered the third or subsequent child (Table 2). However, no differences were found in the percentage of women with different amount of body weight gains according to the respondents' place of residence and age. Also, no significant differences were observed between cigarette smoking and exposure to tobacco smoke and weight gains; nevertheless, the highest percentage of patients with abnormal body weight gains was found among smokers.

Among women who declared consumption of the highest amount of food products supplying proteins of animal origin the percentage of patients with a high gestational weight gain was the highest, whereas consumption of food supplying animal proteins was the lowest among patients with low gain (Table 3 ). 
In addition, a tendency was observed towards a more frequent occurrence of high gains among women who consumed a larger number of portions of sweets, as well as milk and dairy products jointly. However, these relationships were statistically insignificant.

Generally, $20.2 \%$ of respondents declared that they consumed alcohol during pregnancy, most frequently beer (13.8\%), followed by wine (11.9\%), and most rarely high proof alcohol (1.8\%), while $6.4 \%$ of respondents reported that they consumed at least two different types of alcohol. High weight gains in relation to pre-pregnancy BMI were observed significantly more frequently in patients who mentioned alcohol consumption when pregnant, including especially the consumption of beer (Table 4). Women who did not consume alcohol more often had normal weight gains. No differences in gestational weight gains were noted according to the consumption of the remaining beverages; however, a tendency was found towards more frequent occurrence of high weight gains in the group of women who consumed the largest amount of carbonated sweetened beverages.

The results of logistic regression showed that in the group examined, none of the analysed factors was significantly related with an increased risk of low body weight gain during pregnancy (data not shown). Nevertheless it was confirmed that an increased risk of high gain was associated with the consumption of alcoholic beverages, especially beer, high consumption of products supplying proteins of animal origin, i.e. three or more portions daily, as well as overweight, before pregnancy, also the first delivery, compared to the third and subsequent childbirth (Table 5).

\section{Discussion}

Analysis of the data obtained allowed the presumption that in the population examined the frequency of occurrence of high weight gains during pregnancy (39.9\%) was significantly higher, compared to low weight gains (23.4\%). The results of studies carried out in recent years have confirmed that a high percentage of pregnant women reach weight gains exceeding the values recommended by the IOM and NAS [1]. Olafsdottir et al. [8] showed the occurrence of excessive weight gain in $34 \%$ of women, whereas in $26 \%$ - gains lower than the recommended values. Herring et al. [9] found that in approximately $28 \%$ of pregnant women body weight gains were lower than recommended by the IOM, while in $41 \%$ - these gains were higher. Wierzejska et al. [2] reported that as many as $48 \%$ of patients reached gestational weight gain exceeding the recommended values, whereas only $14.2 \%$ obtained weight gain lower than recommended. The results of many studies also confirm that excessive weight gain during pregnancy to the highest degree concerned women who were overweight prior to conceiving, and this occurred in $55-60.5 \%$ of patients [8-10]. The results of our own studies showed that weight gains higher than the recommended values were obtained by as many as $67.4 \%$ of overweight women.

High weight gains during pregnancy were significantly more often noted in primiparas patients, and most rarely in those who gave birth to the third or subsequent child. This may result from the fact that women who delivered for the third or subsequent time were considerably older compared to the total number of respondents; $80.8 \%$ of them were aged 30 or over. According to many researchers young women have higher weight gains during pregnancy [1]. In the presented study, no significant differences in weight gains were found according to the respondents' age; nevertheless, a clear tendency was observed towards reaching higher weight gain among women aged under 30.

The percentages of women who smoked during pregnancy or those exposed to tobacco smoke in their closest environment (10.1\% and 19.5\%, respectively) were close to the results obtained by other researchers. Wojtyła et al. [11] found that $12.2 \%$ of pregnant Polish women smoked during pregnancy. In 15 European countries, $9.24 \%$ of women on average continued smoking in pregnancy, ranging from $4.2 \%$ (Iceland) to $18.9 \%$ (Croatia) [12]. Exposure to tobacco smoke in the closest environment (passive smoking) was declared by $19.2 \%$ of pregnant women from Warsaw [10]. No significant differences in weight gains in the group of women examined were observed according to smoking and exposure to smoke; however, a tendency was noted towards a more frequent occurrence of abnormal weight gain among smokers. Weight gains in accordance with the recommended values were most often found in non-smokers. In the literature, cigarette smoking by pregnant women was most often analysed from the aspect of its effect on birth weight of infants, and the relationship with gestational weight gains in future mothers were considerably less often considered. Analyses by the IOM and NAS show that smokers are at increased risk of occurrence of low weight gain $(\mathrm{OR}=1.3)$ [1].

Excessive body weight gains in pregnancy were related with the consumption of an excessive amount of products supplying proteins of animal origin. According to the recommendations, pregnant women should consume in the first trimester 1 portion of poultry, fish, meat or other protein products daily, and 1.5 portions in the second trimester [7]. In contrast, nearly $57 \%$ of women who had weight gains higher than recommended consumed 3 or more portions of these products daily. It is noteworthy that in this group of products the consumption of fish was very low. More than $60 \%$ of the total number of respondents consumed fish less often than once a week, including $14.8 \%$ who did not consume it at all. High consumption of products of animal origin, includ- 
ing mainly meat and cold cuts, is usually related with a higher energetic value of daily food portions, and a higher content of fat and proteins in the diet, accompanied by a lower content of carbohydrates, which may be conducive to excessive weight gain. The results of studies by other researchers confirm the presence of similar relationships. Lagiou et al. [13] showed that increased gestational weight gains at the end of the second trimester of pregnancy occurred not only in women who consumed meals that were more calorific, but also in those who consumed more proteins and fat of animal origin. Olafsdottir et al. [8] reported that food ratios of overweight women who had excessive weight gains during pregnancy supplied more energy from fat, and less from carbohydrates. Stuebe et al. [14] observed an increased risk of weight gains below the recommendations by the IOM and NAS in women who applied a vegetarian diet in the first trimester of pregnancy.

Consumption of alcoholic beverages during pregnancy was admitted by $20.2 \%$ of the total number of respondents. The results of previously conducted studies indicate large discrepancies in the declared frequency of alcohol consumption by pregnant women, i.e. $15.3-38.5 \%$ in Poland and $5.5-85 \%$ in other European countries [10, 15-20]. Consumption of alcohol in pregnancy, especially beer, was associated with significantly more frequent occurrence of excessive body weight gains. Alcohol may contribute to the development of obesity in many ways, may constitute an important source of calories in the diet, affect the regulation of appetite, and disturb the hormone balance of the body [21]. Alcohol consumption may also be one of the components of the entire complex of anti-health behaviours, which show a tendency towards co-occurrence in the same individuals and may contribute to excessive body weight. Based on longterm studies it was confirmed that the increases in BMI were lower in males who abstained from alcohol $\left(-0.62 \mathrm{~kg} / \mathrm{m}^{2}\right)$ and in females who consumed alcohol more rarely than once a month $\left(-0.38 \mathrm{~kg} / \mathrm{m}^{2}\right)$ compared to those drinking once to twice per month [22]. Analysis of the type of alcohol consumed showed that a high consumption of beer especially contributed to the development of abdominal obesity [23]. To date, few reports have been published concerning the relationship between alcohol consumption by pregnant women and the amount of gestational weight gains. In one of the reports it was mentioned that alcoholic beverages were more often consumed by women with rapid weight gain [24]. However, another report did not confirm the relationship between alcohol consumption and the occurrence of abnormal weight gain in pregnancy [25].

The results of many studies suggest also that physical activity of pregnant women is an important factor determining the amount of gestational weight gain $[9,26,27]$. Thus, the lack of data concerning the physical activity of the examined women is a limitation of the present study. Nevertheless, in literature attention is paid to a generally low level of physical activity among Polish women, both before conception and during pregnancy [28].

The result of intervention studies confirm that changes in the lifestyle of pregnant women contribute to a reduction of the risk of excessive gestational weight gain [26, 27, 29]. Interventions concerning changes in eating habits turned out to be the most effective, leading not only to the reduction of gestational weight gain, but also to the decrease in the risk of pre-eclampsia, pregnancy-induced hypertension, and shoulder dystocia [29]. The presented report, which is an introduction to further studies, confirms an important effect of health behaviours during pregnancy on gestational weight gains. The data obtained will be useful in the elaboration of effective prophylactic programmes for disorders in the nutritional status of pregnant women and the accompanying unfavourable health consequences in the lives of mothers and their children. Pregnancy may be a good moment for women to change their health behaviours, using the additional motivation which, at that time, is the effect on their health of their children.

\section{Conclusions}

The frequency of occurrence of high weight gains during pregnancy in the population examined was considerably higher than that of low weight gains. An increased risk of gestational weight gain higher than recommended was significantly related with many modifiable health behaviours, i.e. consumption of alcoholic beverages during pregnancy, especially beer, increased risk of the consumption of products supplying proteins of animal origin, as well as overweight before becoming pregnant. This study indicates that there is a need for health education among females at reproductive age in order to reduce excess weight before conception, and promotion of adequate health behaviours in pregnancy, which would allow the maintenance of normal weight gain during this period.

\section{Conflict of interest}

The authors declare no conflict of interest.

\section{References}

1. Rasmussen KM, Yaktine AL. Weight gain during pregnancy: reexamining the guidelines. Institute of Medicine, National Research Council of the National Academies. Washington D.C. 2010.

2. Wierzejska R, Jarosz M, Stelmachów J, et al. Gestational weight gain by pre-pregnancy BMI. Postępy Nauk Med 2011; 9: 718-23.

3. Nehring I, Schmoll S, Beyerlein A, et al. Gestational weight gain and long-term postpartum weight retention: a meta-analysis. Am J Clin Nutr 2011; 5: 1225-31. 
4. Li N, Liu E, Guo J, et al. Maternal prepregnancy body mass index and gestational weight gain on pregnancy outcomes. PLoS ONE 2013; 8: e82310.

5. Mannan M, Doi SA, Mamun AA. Association between weight gain during pregnancy and postpartum weight retention and obesity: a bias-adjusted meta-analysis. Nutr Rev 2013; 71: 343-52.

6. Alberico S, Montico M, Barresi V, et al. The role of gestational diabetes, pre-pregnancy body mass index and gestational weight gain on the risk of newborn macrosomia: results from a prospective multicentre study. BMC Pregnancy Childbirth 2014; 14: 23.

7. Szostak-Węgierek D, Cichocka A. Żywienie kobiet w ciąży. Wydawnictwo Lekarskie PZWL, Warsaw 2012.

8. Olafsdottir AS, Skuladottir GV, Thorsdottir I, et al. Maternal diet in early and late pregnancy in relation to weight gain. Int J Obes 2006; 30: 492-9.

9. Herring SJ, Nelson DB, Davey A, et al. 2012. Determinants of excessive gestational weight gain in urban, low income women. Women's Health Issues 2012; 22: 439-46.

10. Wierzejska R, Jarosz M, Sawicki W, et al. Risky health attitudes of pregnant women. Smoking, alcohol, caffeine (in Polish). Pol J Hum Nutr Metab 2011; 38: 84-98.

11. Wojtyła A, Goździewska M, Paprzycki P, et al. Tobaccorelated foetal origin of adult diseases hypothesis - population studies in Poland. Ann Agric Environ Med 2012; 19: 117-28.

12. Smedberg J, Lupatelli A, Mårdby AC, et al. Characteristics of women who continue smoking during pregnancy: a cross-sectional study of pregnant women and new mothers in 15 European countries. BMC Public Health 2014; 14: 213

13. Lagiou P, Tamimi RM, Mucci LA, et al. Diet during pregnancy in relation to maternal weight gain and birth size. Eur J Clin Nutr 2004; 58: 231-7.

14. Stuebe AM, Okem M, Gillman MW. Associations of diet and physical activity during pregnancy with risk for excessive gestational weight gain. Am J Obstet Gynecol 2009; 201: 58.e1-8.

15. Chambers CD, Kavteladze L, Joutchenko L, et al. Alcohol consumption patterns among pregnant women in the Moscow region of the Russian Federation. Alcohol 2006; 38: 133-7.

16. Chambers CD, Yevtushok L, Zymak-Zakutna N, et al. Prevalence and predictors of maternal alcohol consumption in 2 regions of Ukraine. Alcohol Clin Exp Res 2014; 38: 1012-9.

17. Wojtyła A, Kapka-Skrzypczak L, Diatczyk J, et al. Alcoholrelated developmental origin of adult health - population studies in Poland among mothers and newborns (2010-2012). Ann Agric Environ Med 2012; 19: 365-77.

18. Suliga E. Nutritional behaviours of pregnant women in rural and urban environments. Ann Agric Environ Med 2015; 22: 513-7.

19. Murphy DJ, Dunney C, Mullally A, et al. A prospective cohort study of alcohol exposure in early and late pregnancy within an urban population in Ireland. Int J Environ Res Public Health 2014; 11: 2049-63.

20. Skagerström J, Alehagen S, Häggström-Nordin E, et al. Prevalence of alcohol use before and during pregnancy and predictors of drinking during pregnancy: a cross sectional study in Sweden. BMC Public Health 2013; 13: 780.
21. Pimentel GD, Micheletti TO. Alcohol intake and hormonal dysregulation of food intake in visceral fat accumulation. In: Nutrition in the prevention and treatment of abdominal obesity. Watson RR (ed.). Elsevier, Amsterdam 2014; 239-43.

22. Pajari M, Pietiläinen KH, Kaprio J, et al. The effect of alcohol consumption on later obesity in early adulthood - a population-based longitudinal study. Alcohol Alcohol 2010; 45: 173-9.

23. Bergmann MM, Schütze M, Steffen A, et al. The association of lifetime alcohol use with measures of abdominal and general adiposity in a large-scale European cohort. Eur J Clin Nutr 2011; 65: 1079-87.

24. Stevens-Simon C, McAnarney ER. Determinants of weight gain in pregnant adolescents. J Am Diet Assoc 1992; 92: 1348-51.

25. Wells CS, Schwalberg R. Noonan G, et al. Factors influencing inadequate and excessive weight gain in pregnancy: Colorado, 2000-2002. Mater Child Health J 2006; 10: 55-62.

26. Tanentsapf I, Heitmann BL, Adegboye AR. Systematic review of clinical trials on dietary interventions to prevent excessive weight gain during pregnancy among normal weight, overweight and obese women. BMC Pregnancy Childbirth 2011; 11: 1-12.

27. Rauh K, Gabriel E, Kerschbaum E, et al. Safety and efficacy of a lifestyle intervention for pregnant women to prevent excessive maternal weight gain: a cluster-randomized controlled trial. BMC Pregnancy Childbirth 2013; 13: 151.

28. Jarosz M. The need of prenatal public health initiatives in Poland. Ginekol Pol 2012; 83: 854-7.

29. Thangaratinam S, Rogozinska E, Jolly K, et al. Interventions to reduce or prevent obesity in pregnant women: a systematic review. Health Technol Assess 2012; 16: 1-191.

\section{Address for correspondence:}

Prof. JKU Edyta Suliga PhD

Department of the Prevention of Alimentary Tract Diseases Faculty of Medicine and Health Science

Jan Kochanowski University

al. IX Wieków Kielc 19, 25-317 Kielce, Poland

Phone: +48 694898348

E-mail: edyta.suliga@ujk.edu.pl 